\title{
Relationship Between Psychological Distress and Irritable Bowel Syndrome (IBS) in Medical Students of Pelita Harapan University
}

\author{
Steven Nanda*, Veli Sungono* \\ *Faculty of Medicine, Pelita Harapan University, Jakarta \\ **Department of Clinical Epidemiology, Faculty of Medicine, Pelita Harapan University, Jakarta
}

\section{Corresponding author:}

Steven Nanda. Faculty of Medicine, Pelita Harapan University. Jl. Jend. Sudirman No.20 Tangerang Indonesia. Phone: +62-21-54210130; facsimile:+62-21-54210133.E-mail: stevennanda14@gmail.com.

\begin{abstract}
Background: Irritable bowel syndrome (IBS) is a functional disorder with recurrent abdominal discomfort associated with abnormalities in gut motility. One of the risk factors for IBS is anxiety and depression. This study aims to find out the relationship between medical student's psychosocial conditions, measured by depression and anxiety with incidence of IBS. Gastrointestinal-specific anxiety (GSA), a subset of general anxiety, is measured and its relationship with incidence of IBS is also evaluated.

Method: This research is a cross sectional study. Sample consists of 168 medical students from UPH batch 2016-2018 that fits into inclusion and exclusion criteria. Data is collected with demographics questionnaire, Rome IV IBS Criteria, Depression, Anxiety and Stress Scale 21, and Visceral Sensitivity Index. Categorical data between depression and anxiety and IBS is analyzed with Chi-square. GSA is a numerical data and its relationship with IBS is analyzed with t-test. Because GSA All statistical data is analyzed using SPSS version 22.0.

Results: Results showed that from 168 samples that are acquired for this research, 65 (38,7\%) are IBS and $103(61,3 \%)$ are non-IBS. Significant associations are found between depression ( $p=0,03)$, anxiety $(p=0,039)$, gastrointestinal-specific anxiety $(p<0,001)$, and obesity $(p=0,026)$ with incidence of IBS.

Conclusion: There is a significant association between depression and anxiety with incidence of IBS.

Keywords: Irritable bowel syndrome (IBS), psychological distress, depression, anxiety, gastrointestinalspecific anxiety (GSA)

\footnotetext{
ABSTRAK

Latar belakang: Irritable bowel syndrome adalah kelainan fungsional yang ditandai dengan rasa tidak nyaman di perut yang diasosiasikan dengan abnormalitas fungsi usus besar. Distres psikologis, seperti ansietas dan depresi, merupakan faktor risiko terjadinya IBS. Penelitian ini ingin mengetahui adanya hubungan antara kondisi psikososial mahasiswa kedokteran UPH yang ditandai dengan depresi dan ansietas terhadap kejadian IBS. Gastrointestinal-specific anxiety (GSA), subset dari ansietas, diukur dan hubungannya dengan insidens IBS juga dievaluasi.

Method: Penelitian ini menggunakan metode cross-sectional yang dilakukan pada 168 mahasiswa kedokteran UPH angkatan 2016-2018 yang sudah disesuaikan kriteria inklusi dan eksklusi. Pengambilan data dilakukan menggunakan kuesioner demografik sampel, Rome IV IBS Criteria, Depression, Anxiety and Stress Scale 21, dan Visceral Sensitivity Index. Data kategorik antara depresi, ansietas dan IBS diuji dengan Chi Square. GSA memberikan data numerik dan hubungannya dengan IBS diuji dengan t-test. Semua analisa statistik dilakukan menggunakan paket statistik SPSS version 22.0.
} 
Hasil: Hasil penelitian menemukan bahwa dari 168 sampel yang diambil untuk penelitian ini, 65 (38,7\%) di antaranya IBS dan 103 (61,3\%) diantaranya non-IBS. Hasil signifikan ditemukan antara variabel depresi ( $p=0,03)$, ansietas $(p=0,039)$, gastrointestinal-specific anxiety $(p<0,001)$, dan obesitas $(p=0,026)$ dengan kejadian IBS.

Simpulan: Terdapat hubungan signifikan antara depresi dan ansietas dengan kejadian IBS.

Kata kunci: irritable bowelsyndrome (IBS), distres psikologis, depresi, ansietas, gastrointestinal-specific anxiety (GSA)

\section{INTRODUCTION}

Irritable bowel syndrome (IBS) is defined as a syndrome of abdominal pain and discomfort associated with functional abnormality, but not associated with underlying structural, biochemical, or systemic condition. ${ }^{4}$ IBS is categorized as FGID, or functional gastrointestinal disorder. Data shows that FGIDs are still a research topic, especially in the field of epidemiology and clinical practice. IBS continues to be a medical challenge in the 21 st century. ${ }^{1}$ IBS contributes to 1 out of 20 cases of general practitioners; it is also categorized as the most frequent diagnosis by gastroenterologists in United States. ${ }^{5,6}$ One of the factors that may contribute to this statistic is the low awareness of this disease, especially among collegers. ${ }^{6}$

Psychological distress is one of the risk factors that play a role in IBS. According to Husain et al., psychological distress is defined as a negative mental state that poses a direct and indirect influence to the individual, due to the relationship between mental and physical health. Psychological distress includes anxiety, depression, quick to anger, emotional instability, low quality of life, and increasing use of healthcare. Several main stressors that raise mental health problems are anxiety and depression that occur in medical students. Medical students are known to have increased risk of emotional instability. Medical students represent a life style facing burden of workload, including hours of physical and cognitive activities with intense pressure and competition. ${ }^{7,8}$ In theory, this would explain the increased risk of medical students to IBS. A study in Pakistan found the prevalence of IBS as $28.3 \%$ with $55.8 \%$ of them having anxiety symptoms. Another study found $40-50 \%$ of patients suffering FGIDs have moderate-severe psychological disorder. ${ }^{1}$

Several countries like Pakistan, Saudi Arabia, South Korea, and Japan found the prevalence of IBS to be significantly higher among medical students. ${ }^{12}$ Concerning the limited study and demographical condition of Indonesia, this research aims to investigate the relationship between psychological distress in Indonesian medical students with prevalence of IBS.

\section{METHOD}

This research is a cross-sectional study. Population consists of medical students of Pelita Harapan University after meeting inclusion criteria of batch 2016-2018, minimal age of 17, and made informed consent. Exclusion criteria includes history of structural gastrointestinal disease such as colorectal cancer, colon polyp, or inflammatory bowel disease. Independent variable in this research is depression and anxiety symptoms as measure of psychological distress. Anxiety symptom is defined and measured as general anxiety and gastrointestinal-specific anxiety (GSA). Depndent variable in this research is diagnosis of IBS. Confounding variable includes smoking, obesity, and use of long-term medication.

Non-random, purposive sampling is used for the population of this research. Data is collected with the use of questionnaire. First, participants complete a demographic questionnaire to collect biodata and confounding factors of participant. Second, participant fills questionnaire based on ROME IV IBS Criteria to evaluate diagnosis of IBS. Then, participant completes questionnaire of Depression, Anxiety, and Stress Scales-21 (DASS-21) to measure variables of depression and general anxiety. Visceral Sensitivity Index (VSI) questionnaire is also completed to measure gastrointestinal-specific anxiety.

Data that has been collected go through statistical analysis with SPSS version 25.0 and Microsoft Excel 2015.

\section{RESULTS}

Data is collected from questionnaire given to medical students of Pelita Harapan University who agree to be part of the study in the time frame from January 2019 to March 2019.

Demographic results and other variables measured are displayed in Table 1 for categorical data and Table 2 for numerical data. Out of 168 respondents, $103(61.3 \%)$ are categorized as non-IBS group and $65(38.7 \%)$ are categorized as IBS group. Majority of respondents are female (71.4\%) with 120 respondents compared to 48 male respondents (28.6\%). 34 respondents are from batch 2018 (20.2\%), 47 (28.0\%) from batch 2017, and 87 (51.8\%) from batch 2016. Based on height 
and weight, 37 respondents $(22.0 \%)$ are in obesity category as compared to 131 respondents $(78.0 \%)$ in non-obese category. 8 respondents $(4.8 \%)$ have prior smoking history, 25 respondents $(14.9 \%)$ have family history of IBS, 13 respondents $(7.7 \%)$ have history of long-term medication, and 11 respondents $(6.5 \%)$ have diagnostic history of organic gastrointestinal disease.

\begin{tabular}{|c|c|}
\hline Variable & n (\%) \\
\hline $\begin{array}{l}\text { Gender } \\
\text { Male } \\
\text { Female }\end{array}$ & $\begin{array}{l}48(28.6) \\
120(71.4)\end{array}$ \\
\hline \multicolumn{2}{|l|}{ Obesity } \\
\hline Yes & $37(22.0)$ \\
\hline No & $131(78.0)$ \\
\hline \multicolumn{2}{|l|}{ Smoking history } \\
\hline Yes & $8(4.8)$ \\
\hline No & $160(95.2)$ \\
\hline \multicolumn{2}{|l|}{ Family history } \\
\hline Yes & $25(14.9)$ \\
\hline No & $143(85.1)$ \\
\hline \multicolumn{2}{|l|}{ Diagnosis history } \\
\hline Yes & $11(6.5)$ \\
\hline No & $157(93.5)$ \\
\hline \multicolumn{2}{|l|}{ Medication history } \\
\hline Yes & $13(7.7)$ \\
\hline No & $155(92.3)$ \\
\hline \multicolumn{2}{|l|}{ Anxiety } \\
\hline Normal & $98(58.3)$ \\
\hline Mild & $26(15.5)$ \\
\hline Moderate & $28(16.7)$ \\
\hline Severe & $10(6.0)$ \\
\hline Extremely Severe & $6(3.6)$ \\
\hline \multicolumn{2}{|l|}{ Depression } \\
\hline Normal & $117(69.6)$ \\
\hline Mild & $18(10.7)$ \\
\hline Moderate & $27(16.1)$ \\
\hline Severe & $4(2.4)$ \\
\hline Extremely Severe & $2(1.2)$ \\
\hline $\begin{array}{l}\text { Irritable bowel syndrome (IBS) } \\
\text { IBS } \\
\text { Non-IBS }\end{array}$ & $\begin{array}{l}65(38.7) \\
103(61.3)\end{array}$ \\
\hline $\begin{array}{l}\text { Batch } \\
2016 \\
2017 \\
2018\end{array}$ & $\begin{array}{l}75(44.6) \\
51(30.4) \\
42(25.0)\end{array}$ \\
\hline Age (years) & $\begin{array}{l}19.68 \pm 1.00^{*} \\
20.0^{* *} \\
18-26^{\star \star \star}\end{array}$ \\
\hline Gastrointestinal specific anxiety (GSA) & $\begin{array}{l}17.92 \pm 15.02^{*} \\
15.5^{\star *} \\
0-60.0^{* * *}\end{array}$ \\
\hline
\end{tabular}

Two independent variables measured in this study are anxiety and depression symptoms. In the anxiety category, 98 respondents (58.3\%) are categorized as normal; 26 respondents (15.5\%) have mild anxiety; 28 respondents $(16,7 \%)$ have moderate anxiety, 10 respondents $(6,0 \%)$ have severe anxiety; and 6 respondents $(3,6 \%)$ have extremely severe anxiety. In the depression category, 117 respondents $(69.6 \%)$ are categorized as normal, 18 respondents $(10,7 \%)$ have mild depression, 27 respondents $(16,1 \%)$ have moderate depression, 4 respondents $(2,4 \%)$ have severe depression, and 2 respondents $(1,2 \%)$ have extremely severe depression. Average age for the population is 19.68 , with range of age 18-26. Average score of gastrointestinal-specific anxiety is 17.92 with scale of 0 without GSA to 75 which is severe GSA.

In Table 2, respondents are categorized based on IBS or Non-IBS Group and having mild-extremely severe depression or none. Most respondents are categorized as Non-IBS group with no depression. Least respondents are found in non-IBS group with mild-extremely severe depression. Statistical analysis show $\mathrm{p}$ value $=0,003$, Odds Ratio (OR) 2,966 (95\% Confidence Interval $1,504-5,849)$, indicating that depression has significant relationship with IBS incidence. Odds Ratio show that IBS is more likely to occur in respondents having depression with odds value 2.966 .

Next, in anxiety variable, respondents are categorized based on IBS or Non-IBS Group and having mild-extremely severe anxiety or none. Most respondents are categorized as Non-IBS group with no anxiety. Least respondents are found in non-IBS group with no anxiety. Statistical analysis show $\mathrm{p}$ value $=0.039$, Odds Ratio $(\mathrm{OR})=2.041(95 \% \mathrm{CI}$ : $1.084-3.845)$, indicating that anxiety has significant relationship with IBS incidence. Odds Ratio show that IBS is more likely to occur in respondents having anxiety with odds value 2.041 .

Table 3. T-Test comparing GSA and IBS incidence

\begin{tabular}{llll}
\hline $\begin{array}{l}\text { Gastrointestinal } \\
\text { specific anxiety } \\
\text { (GSA) }\end{array}$ & \begin{tabular}{l} 
Irritable bowel syndrome (IBS) \\
\cline { 2 - 3 }
\end{tabular} & $\begin{array}{l}\text { IBS } \\
\text { (Mean } \pm \text { SD) }\end{array}$ & $\begin{array}{l}\text { (Mean } \pm \text { SD) } \\
\text { (Mean }\end{array}$ \\
\cline { 2 - 3 } & $24.46 \pm 15.42$ & $13.79 \pm 13.26$ & $<0.001$ \\
\hline
\end{tabular}

Table 2. Chi-square analysis comparing depression and anxiety with irritable bowel syndrome (IBS) incidence

\begin{tabular}{|c|c|c|c|c|c|}
\hline \multirow[b]{2}{*}{ Variable } & \multicolumn{2}{|c|}{ IBS } & \multirow[b]{2}{*}{ n (\%) } & \multirow[b]{2}{*}{$\mathbf{p}$} & \multirow[b]{2}{*}{ OR $(95 \% \mathrm{Cl})$} \\
\hline & $\begin{array}{l}\text { IBS } \\
\text { n (\%) }\end{array}$ & $\begin{array}{l}\text { Non-IBS } \\
n(\%)\end{array}$ & & & \\
\hline \multicolumn{6}{|l|}{ Depression } \\
\hline Mild-extremely severe & $29(56.9)$ & $22(43.1)$ & $51(30.4)$ & 0.003 & $2.966(1.504-5.849)$ \\
\hline Normal & $36(30.8)$ & $81(69.2)$ & $117(69.6)$ & & \\
\hline \multicolumn{6}{|l|}{ Anxiety } \\
\hline Mild-extremely severe & $34(48.6)$ & $36(51.4)$ & $70(41.7)$ & 0.039 & $2.041(1.084-3.845)$ \\
\hline Normal & $31(31.6)$ & $67(68.4)$ & $98(58.3)$ & & \\
\hline
\end{tabular}


Table 3 shows t-test results between GSA score of non-IBS and IBS group. Figure 1 presents a boxplot result of GSA between IBS and non-IBS group. Average score of GSA in non-IBS group is 13.79; average score of GSA in IBS group is 24.46. Statistical analysis shows $\mathrm{p}$ value $\leq 0.001$ indicating a significant relationship between GSA and IBS incidence.

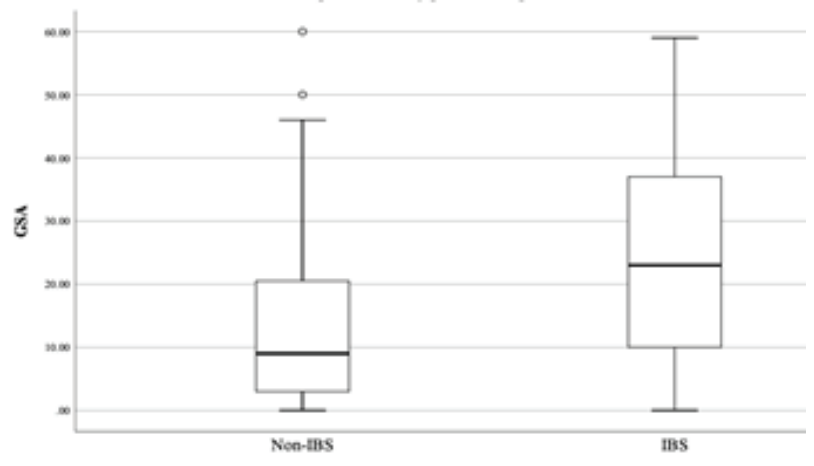

Figure 2. Gastrointestinal specific anxiety (GSA) score in nonIBS group and IBS group - box plot

Table 4. Bivariate analysis of independent \& confounding variables with irritable bowel syndrome (IBS)

\begin{tabular}{|c|c|c|}
\hline Risk factors & $\mathbf{p}$ & OR $(95 \% \mathrm{Cl})$ \\
\hline Gender (female) & 0.153 & $1.795(0.874-3.688)$ \\
\hline Obesity (Obese) & 0.026 & $0.358(0.152-0.843)$ \\
\hline Smoking history & 0.626 & $0.948(0.219-4.109)$ \\
\hline Family history & 0.088 & $2.296(0.971-5.429)$ \\
\hline Diagnostic history & 0.340 & $1.993(0.583-6.819)$ \\
\hline Medication history & 0.143 & $2.751(0.859-8.811)$ \\
\hline $\begin{array}{l}\text { Depression (mild-extremely } \\
\text { severe) }\end{array}$ & 0.003 & $2.966(1.504-5.849)$ \\
\hline $\begin{array}{l}\text { Anxiety (mild- extremely } \\
\text { severe) }\end{array}$ & 0.039 & $2.041(1.084-3.845)$ \\
\hline $\begin{array}{l}\text { Gastrointestinal specific } \\
\text { anxiety }(\mathrm{GSA})^{\star}\end{array}$ & $<0.001$ & \\
\hline
\end{tabular}

Bivariate analysis, as seen in Table 4, shows relationship between gender, obesity, smoking history, family history of IBS, diagnostic history of organic gastrointestinal disease, long-term medication history, depression, anxiety and GSA with IBS incidence. Obesity $(p=0.026)$, depression $(p=0.003)$, anxiety ( $p$ $=0.039), \operatorname{GSA}(\mathrm{p}<0.001)$ show significant relationship with IBS incidence

Multivariate analysis is made to compare independent risk factors with IBS incidence using logistic regression. The odds ratio and $\mathrm{R}^{2}$ value of each independent variable is measured, as seen on the table below.

Table 5 shows 5 of 9 variables with p value $>0,05$ consisting of gender, smoking history, family history with IBS, diagnostic history of organic gastrointestinal disease, and medication history. Each subsequent model removes independent variable with highest $p$ value as seen from table 5-10. A variable is removed from the model if the changes of OR is below $10 \%$ from the previous model. As seen in table 10, the variable "obesity" was not removed from the model because of an OR change that is higher than $10 \%$. The final multivariate model in Table 10 shows variables having statistically significant relationship with IBS incidence that are depression with $p$ value 0,018 and $\mathrm{OR}=2.616(95 \% \mathrm{CI}: 1.133-6.263)$, anxiety with $\mathrm{p}$ value 0,026 and OR 1,312 (95\% CI, 0,652-4,364), and GSA with $\mathrm{p}$ value $<0,001$ and $\mathrm{OR}=1.651$ (95\% CI: $1.259-1.942) . \mathrm{R}^{2}$ value of 0.203 in table 10 shows that $20.3 \%$ of variance in the incidence of IBS is explained by variables of obesity, depression, anxiety and GSA.

$B$ value in table 10 is input to a logistic model based on logistic function $\mathrm{f}(\mathrm{z})$ that represents probability of an outcome based on risk factors. The $\mathrm{z}$ value represents addition of linear constant $\alpha$ with $\beta_{1} X_{1}, \beta_{2} X_{2}$ until $\beta_{\mathrm{i}} \mathrm{X}_{\mathrm{i}}$. Variable $\mathrm{X}$ represents independent variable. Formula for function $\mathrm{f}(\mathrm{z})$ is shown below.

$$
\begin{aligned}
& f(z)=\frac{1}{1+e^{-(\alpha+\beta 1 X 1+\beta 2 \times 2+\cdots+\beta \mathrm{iXi}}} \\
& f(z)=\frac{1}{1+e^{-(-0,397-0,160 \text { (Obesitas) }+0,962(\text { Depresi })+0,335(\text { Ansietas })+0,501(\mathrm{GSA})}}
\end{aligned}
$$

\section{DISCUSSION}

Statistical analysis shows that depression has significant relationship with IBS incidence $(\mathrm{p}=0.003)$ with $\mathrm{OR}=2.966(95 \%$ CI: $1.504-5.849)$ in bivariate analysis. An Odds ratio higher than 1 indicates a positive association between depression and IBS incidence.

The result is supported by previous research that found similar association between depression and IBS incidence. A study by Ebru et al in Turkey in 2007 found the amount of patients suffering depression is higher in IBS group compared to control with a $p$ value $<0.05 .{ }^{24}$ Similar result is also reported by Tan et al in medical students of Malaysia with $\mathrm{p}=0.002 .{ }^{13}$ A study by Lee et al on digestive disorders in Konku University School of Medicine, Seoul, Korea, 2015, found $\mathrm{p}<0.001$ with adjusted $\mathrm{OR}=3.508(95 \% \mathrm{CI}$ : 3.005-4.096) in subjects with depression and IBS. ${ }^{11}$ Other studies also investigated the relationship between depression and IBS and found no significant result, such as a study by Ibrahim et al. in Saudi Arabia in 2013 ( $p=0.112) .{ }^{9}$ Several factors may influence the result such as ethnicity, genetics, culture and lifestyle differences.

In reality, the pathogenesis of IBS is multifactorial and some factors may be more dominant. Several clinicians find psychological distress as a dominant factor in IBS 
Table 5. Multivariate analysis of independent variables with irritable bowel syndrome (IBS) incidence, model I

\begin{tabular}{lccccc}
\hline Risk factors & $\mathbf{B}$ & $\mathbf{p}$ & Adjusted OR & $\mathbf{9 5 \%} \mathbf{C l}$ & $\mathbf{R}^{\mathbf{2}}$ \\
\hline Gender (Female) & 0.408 & 0.184 & 1.504 & $0.972-2.864$ \\
Obesity (Obese) & -0.048 & $\mathbf{0 . 0 3 1}$ & 0.953 & $0.295-1.233$ \\
Smoking history & 0.050 & 0.852 & 1.051 & $0.206-3.511$ & \\
Family history & 0.881 & 0.094 & 2.413 & $1.265-4.427$ & 0.216 \\
Diagnostic history & 0.718 & 0.409 & 2.051 & $0.713-5.412$ & \\
Medication history & 1.050 & 0.183 & 2.860 & $0.739-6.187$ \\
Depression (mild-extremely severe) & 0.945 & $\mathbf{0 . 0 0 8}$ & 2.573 & $1.125-5.926$ \\
Anxiety (mild-extremely severe) & 0.581 & $\mathbf{0 . 0 2 9}$ & 1.788 & $0.573-4.625$ \\
Gastrointestinal specific anxiety (GSA) & 0.524 & $<\mathbf{0 . 0 0 1}$ & 1.689 & $1.183-2.008$ \\
\hline
\end{tabular}

Table 6. Multivariate analysis of independent variables with irritable bowel syndrome (IBS) incidence, model II*

\begin{tabular}{lccccc}
\hline Risk factors & $\mathbf{B}$ & $\mathbf{p}$ & Adjusted OR & $\mathbf{9 5 \%} \mathbf{C l}$ & $\mathbf{R}^{\mathbf{2}}$ \\
\hline Gender (Female) & 0.413 & 0.187 & 1.511 & $0.968-2.871$ & \\
Obesity (Obese) & -0.047 & $\mathbf{0 . 0 3 6}$ & 0.954 & $0.297-1.234$ & \\
Family History & 0.867 & 0.108 & 2.379 & $1.256-4.518$ & 0.213 \\
Diagnostic history & 0.759 & 0.474 & 2.137 & $0.819-5.406$ & \\
Medication history & 1.002 & 0.197 & 2.725 & $0.674-5.929$ & \\
Depression (mild-extremely severe) & 0.952 & $\mathbf{0 . 0 0 9}$ & 2.591 & $1.273-5.972$ & \\
Anxiety (mild-extremely severe) & 0.529 & $\mathbf{0 . 0 2 8}$ & 1.698 & $0.556-4.603$ & \\
Gastrointestinal specific anxiety (GSA) & 0.520 & $\mathbf{0 . 0 0 1}$ & 1.682 & $1.181-1.995$ & \\
\hline
\end{tabular}

"Variable "smoking history" is removed from the model

Table 7. Multivariate analysis of undependent variables with irritable bowel syndrome (IBS) incidence, model III*

\begin{tabular}{lccccc}
\hline Risk factors & $\mathbf{B}$ & $\mathbf{p}$ & Adjusted OR & $\mathbf{9 5 \%} \mathbf{C l}$ & $\mathbf{R}^{\mathbf{2}}$ \\
\hline Gender (Female) & 0.423 & 0.195 & 1.526 & $0.971-2.903$ & \\
Obesity (Obese) & -0.091 & $\mathbf{0 . 0 3 8}$ & 0.913 & $0.273-1.192$ & \\
Family history & 0.858 & 0.114 & 2.358 & $1.251-4.573$ & 0.212 \\
Medication history & 0.993 & 0.183 & 2.698 & $0.668-5.906$ & \\
Depression (mild-extremely severe) & 0.954 & $\mathbf{0 . 0 1 1}$ & 2.596 & $1.274-5.980$ \\
Anxiety (Mild-extremely severe) & 0.486 & $\mathbf{0 . 0 2 8}$ & 1.625 & $0.588-4.486$ \\
Gastrointestinal specific anxiety (GSA) & 0.520 & $<\mathbf{0 . 0 0 1}$ & 1.682 & $1.186-1.951$ \\
\hline
\end{tabular}

"Variable "diagnostic history" is removed from the model

Table 8 Multivariate analysis of independent variables with irritable bowel syndrome (IBS) incidence, model IV*

\begin{tabular}{lcccc}
\hline Risk factors & $\mathbf{B}$ & $\mathbf{p}$ & Adjusted OR $^{\mathbf{9 5} \% \mathbf{C l}}$ & $\mathbf{R}^{\mathbf{2}}$ \\
\hline Obesity (Obese) & -0.129 & 0.051 & 0.879 & $0.265-1.118$ \\
Family history & 0.817 & 0.093 & 2.263 & $1.204-4.577$ \\
Medication history & 0.924 & 0.275 & 2.519 & $0.616-5.562$ \\
Depression (mild-extremely severe) & 0.961 & $\mathbf{0 . 0 1 7}$ & 2.614 & $1.135-6.184$ \\
Anxiety (mild-extremely severe) & 0.427 & $\mathbf{0 . 0 2 6}$ & 1.533 & $0.622-4.391$ \\
Gastrointestinal specific anxiety (GSA) & 0.516 & $<\mathbf{0 . 0 0 1}$ & $\mathbf{1 . 6 7 6}$ & $1.189-1.950$ \\
\hline
\end{tabular}

"Variable "gender (female)" is removed from the model

Table 9. Multivariate analysis of independent variables with irritable bowel syndrome (IBS) incidence, model V*

\begin{tabular}{|c|c|c|c|c|c|}
\hline Risk factors & B & $\mathbf{p}$ & Adjusted OR & $95 \% \mathrm{Cl}$ & $\mathbf{R}^{2}$ \\
\hline Obesity (Obese) & -0.138 & 0.055 & 0.871 & $0.262-1.113$ & \\
\hline Family History & 0.817 & 0.098 & 2.264 & $1.195-4.571$ & \\
\hline Depression (Mild-Extremely Severe) & 0.961 & 0.015 & 2.614 & $1.136-6.184$ & 0.208 \\
\hline Anxiety (Mild-Extremely Severe) & 0.385 & 0.027 & 1.470 & $0.622-4.391$ & \\
\hline Gastrointestinal specific anxiety (GSA) & 0.516 & $<0.001$ & 1.676 & $1.194-1.948$ & \\
\hline
\end{tabular}

"Variable "medication history" is removed from the model

Table 10. Multivariate analysis of independent variables with irritable bowel syndrome (IBS) incidence, model VI*

\begin{tabular}{lcccc}
\hline Risk factors & $\mathbf{B}$ & $\mathbf{p}$ & Adjusted OR $^{\mathbf{9 5} \% \mathbf{C l}}$ & $\mathbf{R}^{\mathbf{2}}$ \\
\hline Obesity (Obese) & -0.160 & 0.058 & 0.852 & $0.241-1.016$ \\
Depression (Mild-Extremely Severe) & 0.962 & $\mathbf{0 . 0 1 8}$ & 2.616 & $1.133-6.263$ \\
Anxiety (Mild-Extremely Severe) & 0.335 & $\mathbf{0 . 0 2 6}$ & 1.398 & $0.652-4.364$ \\
Gastrointestinal specific anxiety (GSA) & 0.501 & $<\mathbf{0 . 0 0 1}$ & 1.651 & $1.259-1.942$ \\
Konstanta & -0.397 & & & \\
\hline
\end{tabular}

"Variable "family history" is removed from the model 
pathogenesis, as seen in previous research. According to Tan et al, individuals with IBS have alteration in their central nervous system response to psychological and physical stimulation. ${ }^{13}$ Both autonomic and neuroendocrine response result in gastrointestinal symptoms with varying severity. This pathogenesis is based on a biopsychosocial model developed by Drossman et al regarding brain-gut axis that connects cenral nervous system to enteric nervous system. ${ }^{10}$ Both systems may experience deregulation duet o changes of neurotransmitter such as serotonin, cholecystokinin and other cytokines. Depression, as studied in this research, could play a role as a psychosocial factor that affects the body's response of releasing neurotransmitter which affects the gut motility and sensitivity

Statistical analysis shows that anxiety has significant relationship with IBS incidence $(\mathrm{p}=0.039)$ with $\mathrm{OR}=$ 2.041 (95\% CI: 1.084-3.845) in bivariate analysis. An odds ratio higher than 1 indicates a positive association between anxiety and IBS incidence. Statistical analysis on GSA also found significant relationship with IBS incidence $(\mathrm{p}<0.001$, adjusted $\mathrm{OR}=1.651,95 \% \mathrm{CI}$ : 1.259-1.942).

This result is supported by several research that highlighted associations between anxiety and IBS incidence. A study by Ibrahim et al in 2013 on medical students of King Abdulaziz University found the prevalence of IBS to be higher in students with anxiety as compared to no anxiety with $\mathrm{p}=0.001$ and $\mathrm{OR}=$ 2.27 (95\% CI: 1.43-3.60). ${ }^{6}$ Another study by Tan et al in 2003 on medical students of University of Malaya, Malaysia reported a similar result with $\mathrm{p}=0.02 .{ }^{13}$ Another study done in Pakistan also found a significant association between anxiety and IBS with $\mathrm{p}<0.001 .{ }^{9}$

The previous studies done explained how medical students experience psychological stressors that are more significant compared to other students as seen from the amount of exams and study material. This stressor could play a role in causing disturbances in gut motility and visceral hypersensitivity.

Another study done in China in 2014 did not find significant relaitonship between anxiety or depression with IBS, despite having higher scores for anxiety and depression in patients with IBS compared to control group. ${ }^{2}$ The author argues that medical students may have better tolerance to psychological stressors because of their daily exposure to exams and hospital practice. The author agrees on psychosocial factors that affect likelihood of IBS through brain-gut axis that changes the central nervous system, neuroendocrine, and immunologic response.
In this study, participant's degree of anxiety is measured in both general anxiety and gastrointestinalspecific anxiety. Results for both variables show significant result, with GSA having smaller $p$ value $p<0,001$ compared to $p=0,026$ of general anxiety. A study by Labu set al. in 2007 found the use of Visceral Sensitivity Index (VSI) questionnaire is important in measuring GSA which also relates to IBS severity. ${ }^{20}$ GSA could be a numerical parameter of a patient's psychological distress severity and GI symptom severity. GSA is a subtype of general anxiety because of its ability to measure anxiety limited to GI symptoms, without considerng other non-GI symptoms. This study used a dominance analysis method to identify the strength of GSA as a variable in paired logistic regression. The result showed VSI as most accurate parameter in IBS diagnosis as compared to other parameter of anxiety with $R^{2}$ value 0.20 to 0.31 or $20-31 \%$ of variance in a population with IBS. The $\mathrm{R}^{2}$ value shows how significant VSI questionnaire in explaining IBS incidence.

In the context of IBS, anxiety measurement should be limited to use of VSI questionnaire as compared to DASS-21 or other general anxiety questionnaire. General anxiety covers complex understanding due to the hierarchical construction of multiple variables including anxiety related to GI, respiration, cognitive, and cardiac. ${ }^{39}$ By utilizing VSI questionnaire which focuses on GSA, measurement of anxiety could be specific to functional gastrointestinal disorders. For instance, non-functional disorders such as colorectal cancer, would likely score lower in VSI questionnaire despite having high symptom severity

A confounding factor that was found to be significant in this study is obesity, with $\mathrm{p}=0.026$ in bivariate analysis and $\mathrm{OR}=0.358$ (95\% CI: 0.152-0.843). An odds ratio less than 1 indicates a negative association between obesity and IBS incidence. This result is contradictory to previous studies that reported obesity as a risk factor to IBS. A study by Lee et al in 2015 measured obesity in specific parameter such as waist length, total adipose fat, subcutaneous adipose tissue, and visceral adipose tissue. ${ }^{11}$ Relationship of obesity with IBS is explained by several factors, such as physical activity and diet. These factors could increase visceral fat percentage which affects gut motility due to increased intraabdominal pressure. Adipokine secretion and cytokines from visceral fat may also trigger inflammation and immunological changes that alters visceral hypersensitivity in IBS patients. 
In a comprehensive review done by Pickett-Blakely, MD, MHS, association between obesity and IBS is found but the underlying mechanism is still unclear. ${ }^{17}$ Limitations such as obesity measurement based on subjective and objective aspects, difference in parameter and cutoff to measure obesity could affect the result of study.

Female gender, smoking history, family history with IBS, diagnostic history of organic gastrointestinal disease, and long-term medication history did not show significant relationship with IBS. Some studies have found these confounding variables to be significant. Female gender may show greater biological susceptibility to gastrointestinal disorders. Sociocultural differences may also affect someone's ability to recognize and treat IBS symptoms without unnecessary hospital visit. ${ }^{42}$ A study in Pakistan and Malaysia9,22 found female gender as a significant variable to IBS incidence. Another study done in Mumbai and Korea ${ }^{8,18}$ found male gender to have significantly higher IBS prevalence which may be explained by cultural barrier that limit female students to report symptoms that they are suffering. Other confounding variables mentioned in this study are still debatable despite having possible explanations. Smoking history, for instance, could affect IBS incidence due to the effects of nicotine that may alter gut transit time. Smoking may also be a general representation of a psychological state that is poor. Further study is required to investigate the significance of other confounding variables.

This study could be generalized to a population with specific age characteristics and limited to medical students. Differences in stress level and knowledge of IBS symptoms in medical students may influence the amount of IBS cases reported and prevalence. Results in this study that are not significant may be affected by limitations of design study, diagnostic criteria used, and sample differences. For instance, an inadequate amount of participants with smoking history may be explained by the smoking habit that is lower in medical students. Other variables such as diagnostic history of organic gastrointestinal disease or long-term medication history may be insigificant in this study due to inadequate samples found in medical students. Previous studies done on this topic found a significant association between family history of IBS and IBS incidence, but a similar result is not found in this study. Differences in genetic and environmental factors may explain this difference, such as history of childhood trauma, parents' attitude towards IBS symptoms, and problems in family relationship.

\section{CONCLUSION}

Result of this study shows significant association between depression, anxiety and gastrointestinalspecific anxiety with incidence of IBS in medical students of Pelita Harapan University.

\section{REFERENCES}

1. Ibrahim NK. A systematic review of the prevalence and risk factors of irritable bowel syndrome among medical students. Turkish J Gastroenterol 2016;27:10-6.

2. Liu Y, Liu L, Yang Y, He Y, Zhang Y, Wang M, et al. A school-based study of irritable bowel syndrome in medical students in beijing, china: prevalence and some related factors. Gastroenterol Res Pr 2014;2014:124261.

3. Chatila R, Merhi M, Hariri E, Sabbah N, Deeb ME. Irritable bowel syndrome: Prevalence, risk factors in an adult Lebanese population. BMC Gastroenterol. 2017;17:1-6.

4. Ferreira N. Investigating the role of psychological flexibility and the use of an acceptance and commitment therapy based intervention in irritable bowel syndrome. Psychology 2011; 2011:x.

5. Qureshi SR, Abdelaal AM, Janjua ZA, Alasmari HA, Obad AS, Alamodi A, et al. Irritable Bowel Syndrome: A Global Challenge Among Medical Students. Cureus 2016;8:1-10.

6. Ibrahim N, Al-Kharboush D, El-Khatib L, Al-Habib A, Asali D. Prevalence and Predictors of Anxiety and Depression among Female Medical Students in King Abdulaziz University, Jeddah, Saudi Arabia. Iran J Public Health 2013;42:726-36.

7. Basandra S. Epidemiology of Dyspepsia and Irritable Bowel Syndrome (IBS) in Medical Students of Northern India. J Clin Diagnostic Res 2014;13-6.

8. Naeem SS et al. "Prevalence and Factors Associated with Irritable Bowel Syndrome among Medical Students of Karachi, Pakistan: A Cross-Sectional Study.” BMC Res Notes 2012;5:255.

9. Ibrahim NKR, Battarjee WF, Almehmadi SA. Prevalence and predictors of irritable bowel syndrome among medical students and interns in King Abdulaziz University, Jeddah. Libyan J Med 2013;8:21287.

10. Drossman DA. Functional gastrointestinal disorders: History, pathophysiology, clinical features, and Rome IV. Gastroenterology 2016;150:1262-1279e2.

11. Lee SP, Sung IK, Kim JH, Lee SY, Park HS, Shim CS. The effect of emotional stress and depression on the prevalence of digestive diseases. J Neurogastroenterol Motil. 2015;21:273-82.

12. Saigo T, Tayama J, Hamaguchi T, Nakaya N, Tomiie T, Bernick PJ, et al. Gastrointestinal specific anxiety in irritable bowel syndrome: Validation of the Japanese version of the visceral sensitivity index for university students. Biopsychosoc Med 2014;8:1.

13. Tan YM, Goh KL, Muhidayah R, Ooi CL, Salem O. Prevalence of irritable bowel syndrome in young adult Malaysians: A survey among medical students. J Gastroenterol Hepatol 2003;18:1412-6.

14. Uz E, Tu C, Aytac S. Risk factors for irritable bowel syndrome in Turkish population: role of food allergy. J Clin Gastroenterol 2007;41:380-3.

15. Taylor S, Cox BJ. Anxiety sensitivity : multiple dimensions and hierarchic structure. Behav Res Ther 1998;36:37-51.

16. Form BSQ, Scale D. The Central Role of GastrointestinalSpecific Anxiety in Irritable Bowel Syndrome : Further Validation of the Visceral Sensitivity Index. :89-98. 
17. Pickett-Blakely O. Obesity and irritable bowel syndrome: A Comprehensive Review 2014;10:411-6.

18. Gwee KA, Ghoshal UC, Chen M. Irritable bowel syndrome in Asia: pathogenesis, natural history, epidemiology, and management. J Gastroenterol Hepatol 2018;33:99-110. 